\title{
Hyperoxia reduces costs of digestion in snakes: potential bioenergetic consequences of the paleoatmosphere
}

This article was published in the following Dove Press journal:

Open Access Animal Physiology

19 October 2010

Number of times this article has been viewed

\author{
Marshall D McCue \\ Department of Biological Sciences, \\ St Mary's University, One Camino \\ Santa Maria, San Antonio, TX, USA
}

Correspondence: Marshall D McCue

Department of Biological Sciences, St Mary's University, One Camino Santa Maria, San Antonio, TX 78228-85I I, USA

Tel + I $21043 \mid 8005$

$\mathrm{Fax}+|21043| 4363$

Email mmccuel@stmarytx.edu
Abstract: Oxygen levels in the Earth's atmosphere fluctuated dramatically during the Phanerozoic eon, and may have reached concentrations that were $60 \%$ higher than current levels. These atmospheric changes have engendered much speculation about the relationship between $\mathrm{O}_{2}$ availability and major evolutionary events among animals (eg, insect gigantism, flapping flight, endothermy). With the exception of studies of exercising humans, a limited number of investigations have examined the potential effects of hyperoxic conditions on physiologic performance variables in animals. Given that the energetic costs of maintenance and digestion can account for the majority of the total energy budget of snakes, this study was conducted to determine the effect of simulated paleoatmospheric oxygen concentration on the metabolic rates of postabsorptive and postprandial snakes. A series of three repeated-measures trials conducted on Western diamondback rattlesnakes under oxygen concentrations ranging from $21 \%$ to $50 \%$ revealed that hyperoxia did not affect resting metabolic rates, but that $35 \%$ $\mathrm{O}_{2}$ was sufficient to reduce specific dynamic action by an average of $11 \%$. Significant increases in respiratory exchange ratios were also observed in postprandial snakes. Given the degree to which extant snakes are energy-limited, such an energetic benefit may have had significant implications for the feeding behaviors and life histories of ancient snakes as they radiated from their lizard ancestors.

Keywords: oxygen limitation, pitvipers, postprandial calorigenesis, rattlesnakes, respiratory quotient, specific dynamic action

\section{Introduction}

All terrestrial animals rely on atmospheric oxygen to carry out the physiologic functions necessary for life. The presumption that the oxygen concentration of the Earth's atmosphere has remained constant over the Phanerozoic eon, espoused by the Gaia hypothesis, ${ }^{1-3}$ has come under increased scrutiny by recent geochemical models consistently reporting that the oxygen concentration on Earth has fluctuated dramatically over the past 500 million years. ${ }^{4-9}$ Although the present atmosphere contains approximately $21 \%$ oxygen, ancient atmospheric oxygen concentrations are likely to have exceeded $30 \%$ around 300 million years before the present, and again as recently as 100 million years before the present ${ }^{7,8}$ (Figure 1).

It has been repeatedly suggested that paleoatmospheric $\mathrm{O}_{2}$ pulses and geological periods of elevated oxygen concentration have been responsible for shaping the morphology and physiology of metazoans through evolutionary time. ${ }^{10,11}$ Specifically, $\mathrm{O}_{2}$ pulses are thought to have permitted the gigantism of insects, ${ }^{12,13}$ as well as the coincidental development of endothermy ${ }^{14,15}$ and flapping flight among birds and 


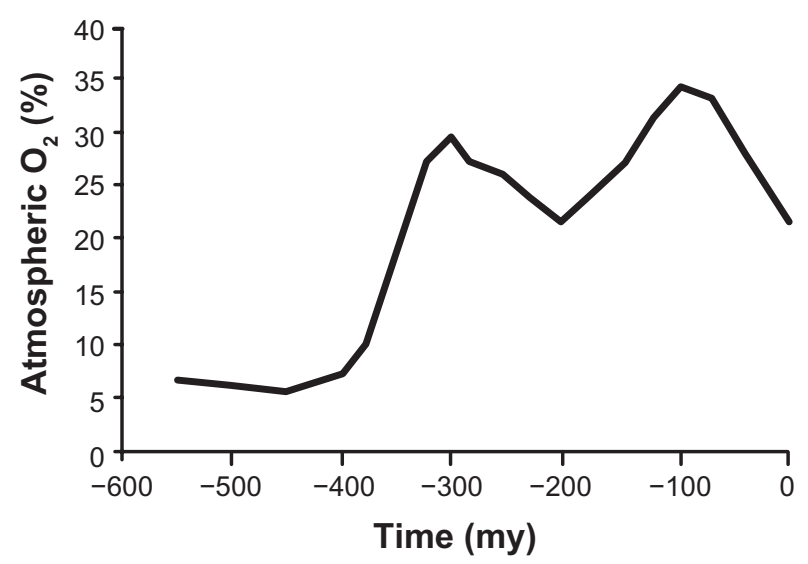

Figure I Paleoatmospheric $\mathrm{O}_{2}$ levels over the past 500 million years. Drawing adapted from geological models. ${ }^{8}$ Two large $\mathrm{O}_{2}$ pulses peaking at approximately 300 and 100 million years before the present.

mammals. ${ }^{16,17}$ Often overshadowed by discussions about the radiation of birds and mammals is the coincidental adaptive radiation of snakes from their lizard ancestor. ${ }^{18,19}$ In fact, since the first snakes appeared over 80 million years before the present, they have come to account for nearly half of all extant reptile species and can be found on six continents. ${ }^{20-24}$ Is it possible that, like insects, birds, and mammals, the evolutionary radiation of snakes may have been facilitated by paleoatmospheric conditions? This study examines the impact that hyperoxia has on one of the most energetically demanding activities of snakes, namely specific dynamic action (SDA).

The energy assimilated from an animal's diet can be routed to several potential sinks, including costs of digestion (ie, SDA), maintenance (resting metabolic rate), activity/locomotion, growth, storage, and reproduction. ${ }^{25,26}$ The proportions of energy allocated to each of these sinks are dictated by each species' life history, and are shaped by natural selection over evolutionary time. ${ }^{27}$ The energetic costs of SDA have been quantified in hundreds of invertebrates and vertebrates, and have been shown to vary widely among species. ${ }^{28,29}$ Over the past decade, snakes have become a model system for investigating digestive energetics because of their comparatively large and prolonged SDA responses, ${ }^{30}$ and several energetic models of pitvipers have determined that the combined costs of resting metabolic rate and SDA are comparatively high, and accounting for the majority of their total assimilated energy. ${ }^{31-35}$

During elevated metabolic states, an animal's physiologic performance is believed to be limited by one of several possible diffusive and convective steps as molecular oxygen enters the body through the lungs (or gills) and is ultimately reduced at the level of the mitochondria. ${ }^{36-39}$ Because the diffusion of molecular oxygen across respiratory surfaces is concentration-dependent, ${ }^{40}$ several physiologists have speculated that pulmonary diffusion could be a limiting step regulating levels of aerobic metabolism, particularly during elevated metabolic states. ${ }^{41-45}$

Numerous studies have shown that aerobic performance can be affected by hyperoxia (Table 1), and two recent studies of fish have shown that the total costs and duration of SDA are increased during exposure to hypoxia. ${ }^{46,47}$ Is it possible that a release from oxygen limitation could influence the costs of SDA? This question is addressed by studying the digestive energetics of the Western diamondback rattlesnake (Crotalus atrox), a widely distributed, heavybodied pitviper. The predictions that hyperoxia will reduce resting metabolic rates in postabsorptive snakes, respiratory exchange ratios of snakes, and energy required to digest a given meal, are examined.

The respiratory exchange ratio refers to the ratio of an animal's rate of $\mathrm{CO}_{2}$ production to $\mathrm{O}_{2}$ consumption. ${ }^{48}$ Because the oxidation of different physiologic fuels (eg, carbohydrates, proteins, and fats) yields different respiratory exchange ratios, these metrics are often used qualitatively to track changes in fuel utilization. While fasting animals generally decrease their respiratory exchange ratio as they progressively increase rates of lipid oxidation, ${ }^{49-53}$ much less is known about how the respiratory exchange ratio is affected by digestion. ${ }^{40,54-58}$

Vipers and pitvipers have been used as models for studying resource limitation for three major reasons. First, their resting metabolic rates are comparatively low, suggesting that these animals may have evolved in conditions where chemical energy is limiting. ${ }^{59-65}$ Second, their SDA responses tend to be larger than in most other snakes. ${ }^{28,66-69}$ Third, resting metabolic rates and postprandial energetic responses are well characterized in these animals under present atmospheric conditions. ${ }^{34,70-72}$

This study was conducted to examine the bioenergetic consequences of living in a hyperoxic atmosphere. Because it is impossible to make physiologic measurements on extinct species in their contemporary environments, we examine how an extant species reacts to artificial atmospheric conditions that mimic ancient atmospheres.

\section{Methods}

\section{Animals}

Adult and subadult Crotalus atrox $(\mathrm{n}=20)$ collected from various localities throughout their range (body 
Table I Studies reporting performance variables in animals under varying hyperoxic conditions

\begin{tabular}{|c|c|c|c|c|}
\hline Organism & $\mathrm{O}_{2}$ condition & Exposure & Result & Reference \\
\hline Bats & $35 \%$ & acute* & no improved hovering performance in hypodense air $\left(\mathrm{H}_{2}\right)$ & 120 \\
\hline Cat mesentery & hyperoxia & acute & no changes in blood flow in an in vitro preparation & 121 \\
\hline Chicken eggs & $60 \%$ & chronic & increased development rate and larger embryos & 122 \\
\hline Drosophila adults & $40 \%$ & chronic & reduced life span from approximately 55 to 35 days & 115 \\
\hline Drosophila pupae & $40 \%$ & chronic & caused shorter/fatter adult bodies & 123 \\
\hline Frog eggs & $99 \%$ (7 ATM) & acute & incomplete or retarded gastrulation & 124 \\
\hline Guinea pigs & $45 \%$ & acute & $\begin{array}{l}\text { accelerated clearance of bacterial infection (via increased } \\
\text { neutrophil activity) }\end{array}$ & 125 \\
\hline Humans & $60 \%$ & acute & no changes in ventilation, heart rate, or lactate during exercise & 14 \\
\hline Humans & $50 \%$ & chronic & no toxic effects observed & 111 \\
\hline Humans & $100 \%$ & acute & vasoconstriction but increased peripheral $\mathrm{pO}_{2}$ & 126 \\
\hline Humans & hyperoxia & acute & downregulation of vascular endothelial growth factor & 127 \\
\hline Humans & $50 \%$ & acute & increased $\mathrm{O}_{2}$ debt recovery & 79 \\
\hline Humans & $100 \%$ & acute & increased $\mathrm{O}_{2}$ delivery and ultimately $\mathrm{VO}_{2}$ max of leg & 42 \\
\hline Humans & $21 \%(1.4$ ATM $)$ & acute & $\begin{array}{l}\text { reduced } \mathrm{O}_{2} \text { deficit and lactate accumulation at submaximal } \\
\text { exercise, and increased performance at } \mathrm{VO}_{2} \max \end{array}$ & 128 \\
\hline Humans & $70 \%$ & acute & increased ventilatory threshold at near maximal exercise & 45 \\
\hline Humans & $100 \%$ & acute & $\begin{array}{l}\text { exercising humans did not influence } \mathrm{VO}_{2}, \mathrm{O}_{2} \text { delivery, or blood } \\
\text { pressure of leg, but reduced blood flow }\end{array}$ & 129 \\
\hline Humans (lung disease) & $60 \%$ & acute & reduced heart rate and ventilation requirements during exercise & 130 \\
\hline Hummingbirds & $33 \%$ & acute & $\begin{array}{l}\text { females had slight improvement in hovering performance in } \\
\text { hypodense gas, } \mathrm{O}_{2} \text { diffusion was not limited }\end{array}$ & $|3|$ \\
\hline Lambs & $33 \%-46 \%$ & acute & $\begin{array}{l}\text { increased summit metabolism (ie, cold-induced } \mathrm{VO}_{2} \text { max), } \\
\text { improved cardiac output }\end{array}$ & 132 \\
\hline Lizard eggs & $30 \%$ & chronic & no difference in egg incubation times & 133 \\
\hline Mouse pups & $85 \%$ & chronic & $\begin{array}{l}\text { retarded histologic development in lungs, and reduced } \\
\text { lung compliance }\end{array}$ & 134 \\
\hline Quail eggs & $60 \%$ & acute & no changes in embryonic wet mass or rates of $\mathrm{O}_{2}$ consumption & 135 \\
\hline Rat pups & $95 \%$ & acute & reduced weight gain and increase oxidase enzyme levels in lungs & 110 \\
\hline Rat pups & $60 \%$ & chronic & caused reduced hypoxia tolerance & 136 \\
\hline Rat pups & $60 \%$ & chronic & adults had attenuated physiological responses to hypoxia & 137 \\
\hline Rats & $85 \%$ & acute & reduced capillary vascularization and hematocrit & 138 \\
\hline Rats & $100 \%$ & chronic & $\begin{array}{l}\text { partial hemolysis of red blood cells, altered hemoglobin levels, } \\
\text { edema of alveolar tissues }\end{array}$ & 139 \\
\hline Rats & $100 \%$ & acute & reduced cardiac output, cerebral blood flow, and heart rates & 140 \\
\hline Rats & $42 \%$ & acute & no abnormal histology & $|4|$ \\
\hline Rats (wounded) & $100 \%(2.5$ ATM $)$ & acute & increased vascular endothelial growth factor and reduced lactate & 112 \\
\hline Sea snake & $100 \%$ & acute & reduced ventilation rates & 142 \\
\hline Tortoise/turtle & $100 \%$ & acute & reduced ventilation rates & 143 \\
\hline Turtles & $100 \%$ & acute & reduced ventilation rates & 92 \\
\hline
\end{tabular}

Note: *Acute exposure refers to less than 14 days.

masses 339-1145 g) were donated to this project by E Taylor (Arizona State University, AZ), J Bibby (Fort Worth, TX), and $\mathrm{C}$ Guyer (Auburn University, AL). Prior to the experimental feeding trials, snakes were housed individually in locking plastic cages, and acclimated to laboratory conditions that simulated their active/feeding season $\left(27 \pm 1^{\circ} \mathrm{C}\right.$; 12 hours light, 12 hours dark) for a minimum of 12 weeks. During the acclimation period, all snakes consumed at least eight meals consisting of commercially raised prekilled feeder mice (Rodent Pro, Inglefield, IN), and were fasted for two weeks prior to feeding experiments to ensure that they were postabsorptive.

\section{Experimental design}

This study consisted of a series of three experiments, each employing a complete, repeated-measures design, thereby facilitating comparisons of metabolic responses under different oxygen concentrations.

In experiment 1 , animals $(\mathrm{n}=8 ; 830 \mathrm{~g}$, standard deviation $[\mathrm{SD}] \pm 187 \mathrm{~g}$ ) were fed two prekilled mice (combined mass of approximately $47 \mathrm{~g}$; approximately $6 \%$ relative prey mass). Immediately after ingesting the meals, each snake was placed into a $4 \mathrm{~L}$ polypropylene respirometry chamber and exposed to one of three oxygen concentrations (ie, $21 \%, 35 \%$, and $50 \%$ ) wherein 
postprandial metabolic rates were quantified each hour during the subsequent 120 hours.

Several variables, including body mass, meal mass, resting metabolic rate (RMR), energy of SDA, time to peak SDA $\left(\mathrm{T}_{\text {peak }}\right)$, scope of postprandial metabolic increase $\left(\mathrm{SDA}_{\text {scope }}\right), \mathrm{SDA}$ coefficient $\left(\mathrm{SDA}_{\text {coeff }}\right)$, and $\left(\mathrm{RER}_{\text {peak }}\right)$ were compared among the three treatment levels using repeatedmeasures one-way analysis of variance (ANOVA), and Fisher's protected least significant difference. The SDA, $\mathrm{SDA}_{\text {coeff }}$, and $\mathrm{SDA}_{\text {scope }}$ were calculated using the following standard equations: $:^{28,29}$

$$
\begin{gathered}
S D A=\left(m l_{02 \text { consumed }} * K\right)-(R M R * t) \\
S D A_{\text {scope }}=S D A_{\text {peak }} / R M R \\
S D A_{\text {coeff }}=\frac{S D A}{E_{\text {ingested }}}
\end{gathered}
$$

where $K$ is $20.28 \mathrm{~kJ}^{*} \mathrm{ml} \mathrm{O}_{2}{ }^{-1,31,51,73-75} t$ is the duration of the trials in hours, $\mathrm{SDA}_{\text {peak }}$ is the highest observed postprandial metabolic rate, and $\mathrm{E}_{\text {ingested }}$ is $7.02 \mathrm{~kJ}^{*} \mathrm{~g}^{-1} \cdot{ }^{76}$ Resting metabolic rate was calculated as the mean metabolic rate of postabsorptive animals at rest, measured hourly for 24 hours prior to each feeding trial at the same oxygen concentration as each of the feeding treatments. The first hour of resting metabolic rate measurements were omitted from the analyses to avoid the inclusion of short-term stress responses associated with handling.

Experiment 2 employed the eight animals from the first experiment ( $\mathrm{n}=8 ; 867 \pm 186 \mathrm{~g}$ ), but used larger meal sizes (ie, three mice totaling approximately $101 \mathrm{~g}$; approximately $12 \%$ relative prey mass). After a three-week period of fasting, the snakes were fed a meal and exposed to $35 \% \mathrm{O}_{2}$ for 144 hours. Three weeks later, the snakes were fed a similar-sized meal and subjected to $21 \% \mathrm{O}_{2}$ over the subsequent 144 hours.

Experiment 3 employed a second set of smaller snakes $(\mathrm{n}=12 ; 410 \pm 76 \mathrm{~g})$. The snakes were fasted for three weeks and fed meals consisting of three mice with combined masses of approximately $64 \mathrm{~g}$ (approximately 15\% relative prey mass). Snakes were subjected to $35 \% \mathrm{O}_{2}$, and SDA measurements were also made over the subsequent 144 hours. Three weeks later, the feedings and SDA measurements were repeated at $21 \% \mathrm{O}_{2}$. The same variables were monitored as in the trial 1 , but one-tailed, paired $t$-tests were used to compare responses between $21 \%$ and $35 \% \mathrm{O}_{2}$. Because of the unexpectedly high variability in responses among snakes subjected to $50 \% \mathrm{O}_{2}$ during trial 1 , the $50 \% \mathrm{O}_{2}$ treatment was not used in experiments 2 and 3 . The total duration of the
SDA response was not analyzed because of the difficulty in reliably distinguishing SDA from small diel variations in resting metabolic rate. ${ }^{77}$

These experiments were conducted in accordance with University of Arkansas Animal Care and Use Committee protocol number 080107.

\section{Gas control and measurement}

A stream of dry $\mathrm{O}_{2}$ generated using a Devilbiss- $515^{\circledR} \mathrm{O}_{2}$ concentrator (Devilbiss, Somerset, PA) capable of producing a constant supply of $95 \% \mathrm{O}_{2}$ at up to $5 \mathrm{~L}$ per minute was combined with room air inside a mixing chamber ported with one-way valves (Figure 2). The gas inside the mixing chamber was circulated using a standard $90 \mathrm{~mm}$ brushless computer fan and was pumped through a Drierite ${ }^{\mathrm{TM}}$ column (Cole-Parmer, Vernon Hills, IL). The dried gas mixture then entered a second surge tank to dampen the oscillations caused by the diaphragm pump and to minimize potential fluctuations in $\mathrm{O}_{2}$ concentration.

The gas mixture then entered an MF-8 manifold (Sable Systems $^{\mathrm{TM}}$, Las Vegas, NV) where it was split into eight gas streams that passed through the individual metabolic chambers. The first metabolic chamber was always left unoccupied and served as a measure of baseline (ie, incurrent) gas concentrations. Gases exiting the metabolic chambers were pushed through a Sable Systems RM-8 multiplexer programmed to divert individual gas streams into a subsampling junction serially every $7-8$ minutes, thereby allowing the metabolic rate of each animal to be measured hourly.

A subsample of each gas stream was pulled through a second desiccant column (approximately $60 \mathrm{~mL} / \mathrm{min}$ ) followed by an Ametek ${ }^{\mathrm{TM}}$ (Paoli, PA) CD-3A carbon dioxide analyzer (spanned with dry $\mathrm{N}_{2}$ and $10 \% \mathrm{CO}_{2}$; Air Liquid America Specialty Gases, Pasadena, TX) and an Ametek ${ }^{\mathrm{TM}}$ S-3 $\mathrm{A} \mathrm{O}_{2}$ analyzer (spanned using $\mathrm{N}_{2}$ and dry air) using a vacuum pump and flow controller. Oxygen and carbon dioxide concentrations were recorded constantly.

All measurements of $\mathrm{O}_{2}$ consumption and $\mathrm{CO}_{2}$ production were calculated using modified Fick's equations corrected for STP, ${ }^{60,70,72,78}$ assuming that rates of gaseous nitrogen flux during hyperoxic treatments were not significantly different from those under normoxia; see calculations and discussions in previous studies. ${ }^{79-81}$ In order to standardize for differences in SDA responses resulting from the slight variations in meal sizes among animals within respective experiments, the measured SDA responses were corrected to the mean meal mass for each experiment assuming an isometric SDA response over a relatively narrow range of meal sizes differing by less than $4 \mathrm{~g}$. 


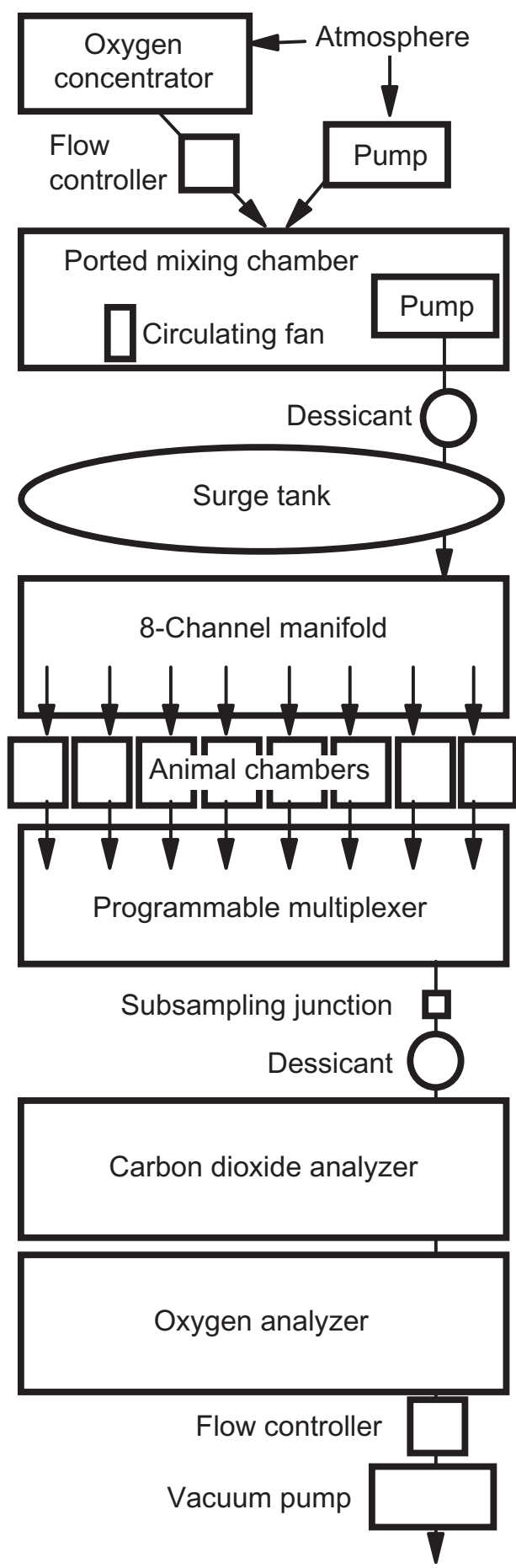

Figure 2 Hyperoxia-generating respirometry system. Open-flow respirometry system capable of producing controlled hyperoxic gas mixtures (ranging from $21 \%$ to $70 \% \mathrm{O}_{2}$ ) to eight metabolic chambers at flows up to $2 \mathrm{~L} / \mathrm{min}$.

A pilot study designed to monitor the consistency of the oxygen concentration gas streams and flow rates through animal chambers found less than a $0.01 \%$ change in oxygen concentration over a one-hour period at $35 \% \mathrm{O}_{2}$ and a $0.02 \%$ fluctuation at $50 \% \mathrm{O}_{2}$. Drift in oxygen concentration was always less than $0.001 \%$ over a one-hour period. Flow rates through empty metabolic chambers ranged between 100 and $400 \mathrm{~mL} / \mathrm{min}$ and were continually measured using a Sable Systems FoxBox. During a 24-hour period flow rates did not fluctuate by more than $1 \%$ of their initial value.

\section{Results}

\section{Experiment I}

Repeated-measures ANOVAs comparing resting metabolic rate and SDA results revealed that only $\mathrm{T}_{\text {peak }}$ differed among the three treatments $(P=0.010)$; no differences in resting metabolic rate were detected. Post hoc tests showed that $\mathrm{T}_{\text {peak }}$ responses at $35 \% \mathrm{O}_{2}$ were significantly different from those at $21 \%$ and $50 \% \mathrm{O}_{2}$. Two-tailed pairwise comparisons of responses measured at $21 \%$ and $35 \% \mathrm{O}_{2}$ were statistically significant for SDA, $\mathrm{SDA}_{\text {corr }}, \mathrm{T}_{\text {peak }}, \mathrm{SDA}_{\text {scope }}$, and $\mathrm{SDA}_{\text {coeff }}$ (Table 2, Figure 3A).

\section{Experiment 2}

One-tailed, pairwise comparisons revealed that SDA, SDA $\mathrm{T}_{\text {peak }}, \mathrm{SDA}_{\text {scope }}$, and $\mathrm{SDA}{ }_{\text {coeff }}$ were significantly reduced in $35 \%$ $\mathrm{O}_{2}$ (Table 2, Figure 3B); no differences in resting metabolic rate were detected. Respiratory exchange ratios reduced sharply upon ingestion and then increased rapidly during the first 10 hours of digestion. A less rapid increase in respiratory exchange ratio toward postabsorptive values was observed during the final stages of SDA (Figure 4A).

\section{Experiment 3}

One-tailed, pairwise comparisons showed that SDA, SDA $\mathrm{SDA}_{\text {scope }}$, and $\mathrm{SDA}_{\text {coeff }}$ were significantly reduced under $35 \%$ $\mathrm{O}_{2}$ (Table 2, Figure 3C), but no differences in resting metabolic rate were observed between normoxic and hyperoxic treatments. As in the second experiment, respiratory exchange ratios increased sharply during the first 10 hours of digestion from values of approximately 0.50 to 0.60 , before ultimately increasing at a more gradual rate reaching values of $0.70-0.80$ near the end of the SDA response (Figure 4B).

\section{Discussion}

The results of this experiment did not support the prediction that resting metabolic rate was influenced by gas mixtures containing up to $50 \% \mathrm{O}_{2}$, but do show that postprandial energy expenditure was influenced by inspired oxygen concentration. In all experiments, a level of $35 \% \mathrm{O}_{2}$ was sufficient to reduce three interrelated variables associated with postprandial energetics, ie, total energy required for meal digestion and absorption (ie, SDA), peak postprandial metabolic rate (ie, $\mathrm{SDA}_{\text {scope }}$ ), and the relationship between 
Table 2 Results of feeding experiments during which pitvipers were allowed to digest meals under normoxia and hyperoxia

\begin{tabular}{|c|c|c|c|c|}
\hline & $21 \%$ & $35 \%$ & $50 \%$ & $\boldsymbol{P}$ \\
\hline \multicolumn{5}{|c|}{ Experiment I } \\
\hline Mass (g) & 811 [188] & $836[186]$ & $843[187]$ & \\
\hline \multicolumn{5}{|l|}{ (mL O $\mathrm{O}_{2}$ /hour) } \\
\hline Meal $(\mathrm{g})$ & $46.9[2.2]$ & $48.2[2.0]$ & $46.9[1.8]$ & \\
\hline SDA (kJ) & $52.9[7.0]$ & $46.2[2.6]$ & $52.3[12.6]$ & $0.035^{*}$ \\
\hline $\mathrm{SDA}_{\text {corr }}(\mathrm{kJ})$ & $56.5[8.3]$ & $48.0[2.9]$ & $56.1[16.2]$ & $0.015^{*}$ \\
\hline $\mathrm{T}_{\text {peak }}$ (hours) & $33.0[5.4] \mathrm{b}$ & $24.1[1.3] \mathrm{a}$ & $32.6[8.5] \mathrm{b}$ & $0.003 *$ \\
\hline $\mathrm{SDA}_{\text {scope }}$ & $3.6[0.8]$ & $3.5[1.1]$ & $3.3[0.9]$ & $0.021 *$ \\
\hline $\mathrm{SDA}_{\text {coeff }}(\%)$ & I6.I [2.2] & $13.9[0.8]$ & I5.9 [4.6] & $0.015 *$ \\
\hline \multirow{3}{*}{$\mathrm{RER}_{\text {peak }}$} & 0.668 & 0.665 & 0.671 & \\
\hline & [0.029] & {$[0.057]$} & {$[0.035]$} & \\
\hline & $\mathrm{n}=8$ & $\mathrm{n}=8$ & $\mathrm{n}=8$ & \\
\hline \multicolumn{5}{|c|}{ Experiment 2} \\
\hline Mass (g) & 879 [183] & $856[188]$ & - & \\
\hline \multicolumn{5}{|l|}{ (mL $\mathrm{O}_{2}$ /hour) } \\
\hline Meal $(g)$ & $100.9[4.2]$ & $101.9[4.8]$ & - & \\
\hline SDA (kJ) & $118.0[11.4]$ & $102.6[15.1]$ & - & 0.029 \\
\hline $\mathrm{SDA}_{\text {corr }}(\mathrm{kJ})$ & $117.0[10.5]$ & $100.8[15.1]$ & - & 0.030 \\
\hline $\mathrm{T}_{\text {peak }}$ (hours) & $37.1[3.3]$ & $32.3[4.7]$ & - & 0.014 \\
\hline $\mathrm{SDA}_{\text {scope }}$ & $5.1[1.0]$ & $4.2[0.8]$ & - & $<0.001$ \\
\hline $\mathrm{SDA}_{\text {coeff }}(\%)$ & $16.7[1.5]$ & I5.3 [2.I] & - & 0.003 \\
\hline \multirow[t]{3}{*}{$\mathrm{RER}_{\text {peak }}$} & 0.642 & 0.649 & - & \\
\hline & {$[0.014]$} & {$[0.013]$} & & \\
\hline & $\mathrm{n}=8$ & $\mathrm{n}=8$ & & \\
\hline \multicolumn{5}{|c|}{ Experiment 3} \\
\hline Mass (g) & $4 \mid 2$ [77] & 408 [74] & - & \\
\hline RMR & $14.9[2.1]$ & I5.6 [2.5] & - & \\
\hline \multicolumn{5}{|l|}{ (mL $\mathrm{O}_{2} /$ hour) } \\
\hline Meal $(\mathrm{g})$ & $64.0[1.6]$ & $63.4[1.7]$ & - & \\
\hline SDA (kJ) & $73.9[9.4]$ & $69.4[7.6]$ & - & 0.016 \\
\hline $\mathrm{SDA}_{\text {corr }}(\mathrm{kJ})$ & $73.9[5.4]$ & $69.3[7.7]$ & - & 0.019 \\
\hline $\mathrm{T}_{\text {peak }}$ (hours) & $39.3[5.2]$ & $39.5[4.2]$ & - & \\
\hline $\mathrm{SDA}_{\text {scope }}$ & $5.1[1.0]$ & $4.2[0.8]$ & - & 0.002 \\
\hline $\mathrm{SDA}_{\text {coeff }}(\%)$ & $16.6[1.4]$ & I5.4 [I.7] & - & 0.006 \\
\hline \multirow[t]{3}{*}{$\mathrm{RER}_{\text {peak }}$} & 0.658 & 0.675 & - & \\
\hline & [0.034] & {$[0.025]$} & & \\
\hline & $\mathrm{n}=12$ & $\mathrm{n}=12$ & & \\
\hline
\end{tabular}

Notes: Values in brackets refer to one standard deviation. Relevant assumptions are explained in the Methods section. Letters beside values refer to responses that were statistically different according to post hoc tests. Only significant $P$ values are shown. *Two-tailed, paired $t$-tests between $21 \%$ and $35 \% \mathrm{O}_{2}$ were used; all other $P$ values refer to one-tailed, paired $t$-tests.

Abbreviations: RMR, respiratory metabolic rate; SDA, specific dynamic action; $T_{\text {peak }}$, time to peak SDA; SDA ${ }_{\text {scope }}$, scope of postprandial metabolic increase; SDA ${ }_{\text {coeff' }}$ SDA coefficient; $R_{\text {peak }}$, respiratory exchange ratio at peak SDA; SDA $A_{\text {corr }}$

ingested energy and energy required for digestion and assimilation (ie, $\mathrm{SDA}_{\text {coeff }}$ ). On average, the animals required $11 \%$ less energy to process meals under $35 \% \mathrm{O}_{2}$ compared with normoxia. For pitvipers, that might only consume eight or nine meals during an entire feeding season, ${ }^{32}$ the "savings" realized from digestion under hyperoxic conditions could translate to an annual "free" meal. Two of the three
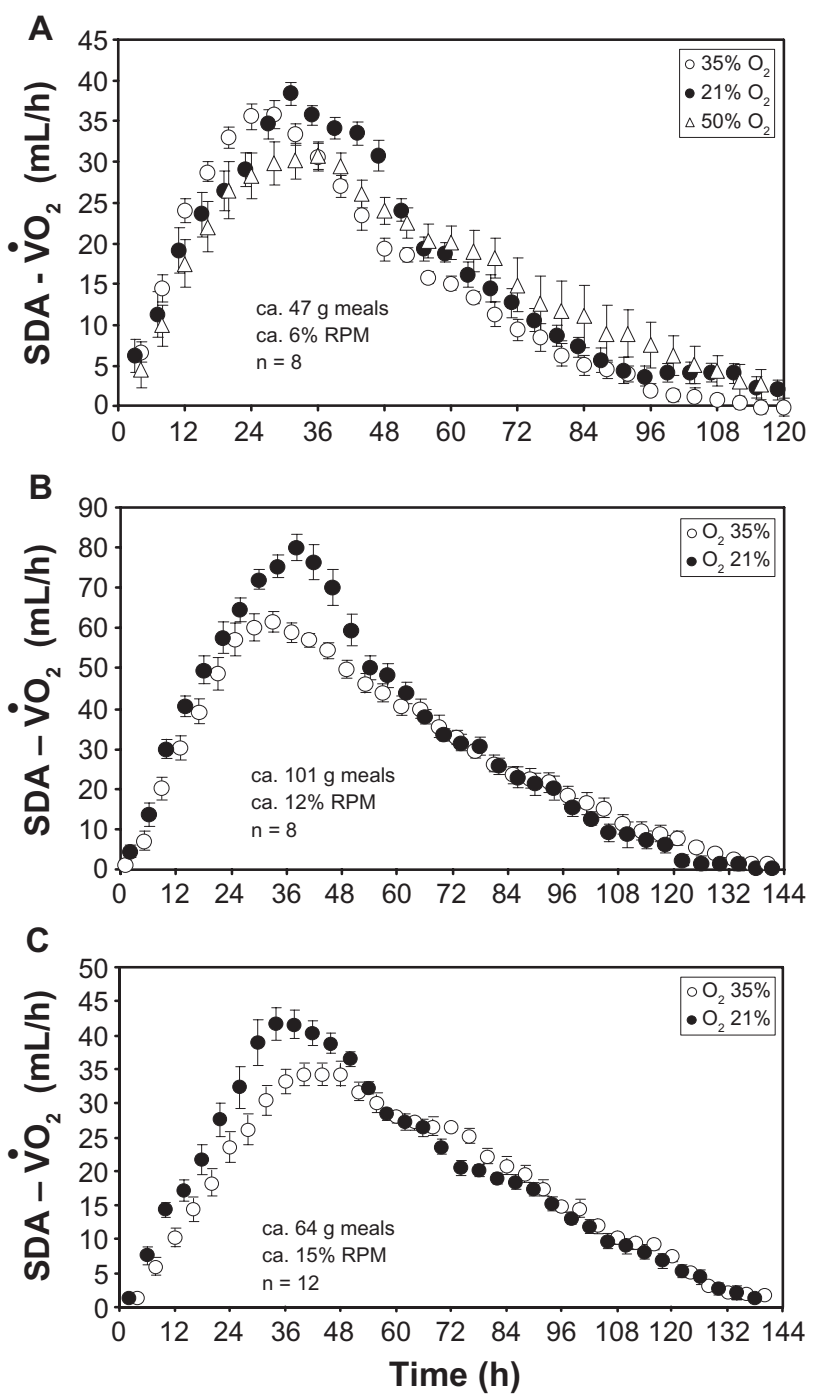

Figure 3 Specific dynamic action responses under normoxia and hyperoxia in pitvipers measured during the three experiments. A) Snakes $(n=8)$ ingesting approximately. $47 \mathrm{~g}$ mouse meals subjected to three $\mathrm{O}_{2}$ treatment levels. B) Snakes $(\mathrm{n}=8)$ ingesting approximately $\mathrm{IOI} \mathrm{g}$ mouse meals subjected to two $\mathrm{O}_{2}$ treatment levels. C) Snakes $(n=12)$ ingesting approximately 64 g mouse meals subjected to two $\mathrm{O}_{2}$ treatment levels. Error bars refer to \pm one standard error of the mean. For clarity, data points are slightly offset along the x-axis.

experiments showed that hyperoxic conditions resulted in lower $\mathrm{T}_{\text {peak }}$ values, supporting the prediction that hyperoxia influences the time course of SDA; however, because the difference was not significant in the final experiment, it remains possible that this response could be a statistical artifact.

The specific mechanisms underlying the reduction in SDA under hyperoxia remain untested, but might involve a reduction in lactate production ${ }^{58,82-85}$ and the subsequent costs of gluconeogenesis, ${ }^{28,86-89}$ as well as reduced ventilatory ${ }^{40,90-93}$ and circulatory costs. ${ }^{94-98}$ Future experiments designed to monitor the effects of hyperoxia on blood oxygen concentration, ventilation, heart rates, and lactate flux will be needed to examine each of these possibilities. 


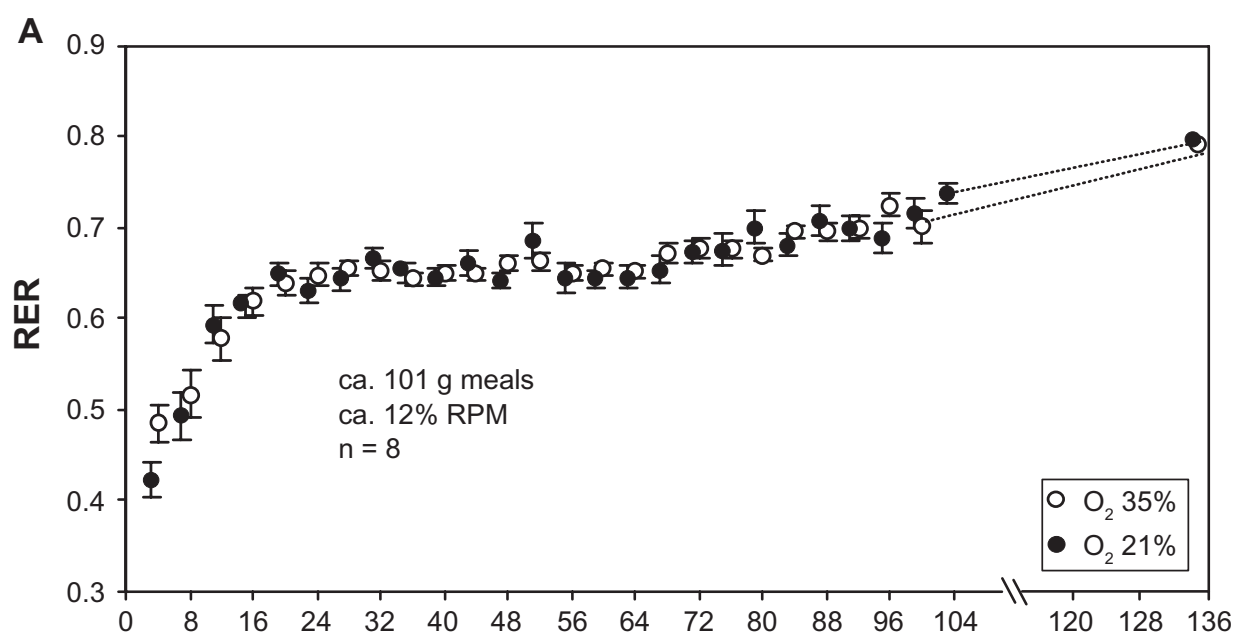

B

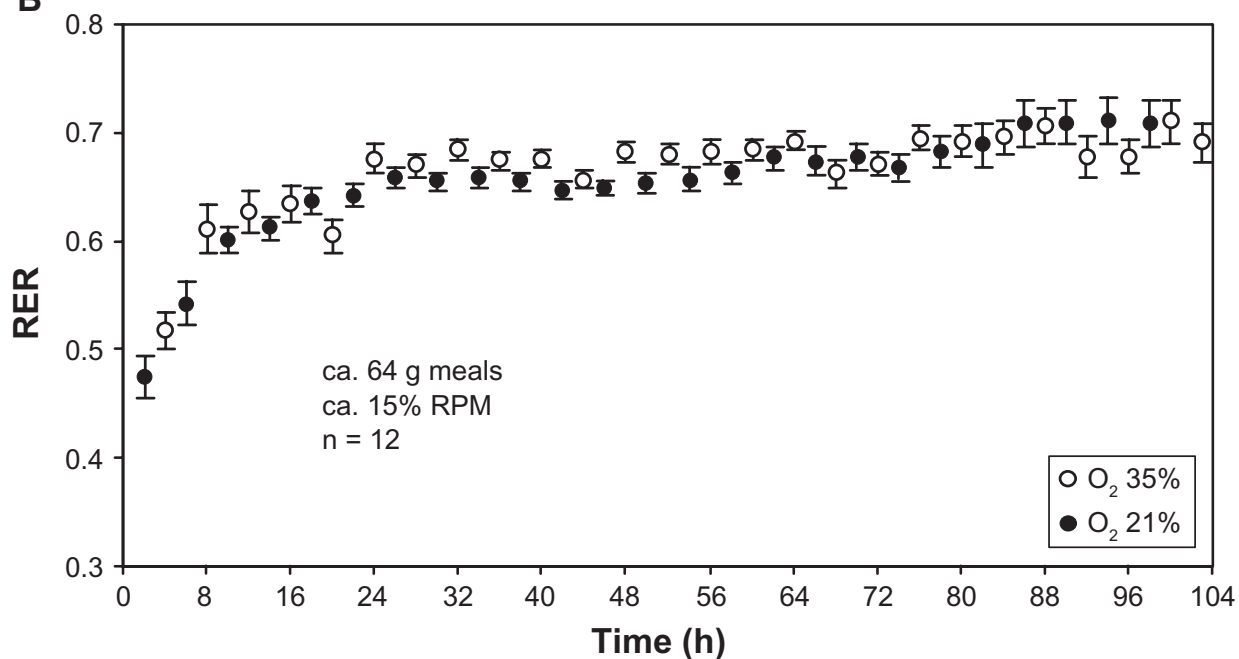

Figure 4 Respiratory exchange ratios in postprandial snakes subjected to normoxia and hyperoxia. Measurements of respiratory exchange ratio made in postprandial pitvipers subjected to two $\mathrm{O}_{2}$ treatment levels. A) Snakes $\mathrm{n}=8$ ingesting approximately $10 \mathrm{I} \mathrm{g}$ mouse meals. B) Snakes $(\mathrm{n}=12)$ ingesting approximately $64 \mathrm{~g}$ meals. Error bars refer to \pm one standard error of the mean. For clarity, data points are slightly offset along the x-axis.

Given that the meals used in these experiments were not near the upper limit that these animals can ingest, it may also be worthwhile to examine how hyperoxia influences snakes digesting extremely large meals (eg, relative prey masses in the range $50 \%-100 \%$ ) where $\mathrm{SDA}_{\text {scope }}$ may exceed a value of $20.29,30,99,100$

No differences between respiratory exchange ratios during exposure to normoxia and hyperoxia were noted among postprandial or postabsorptive snakes. This finding did not support the prediction that hyperoxic conditions might preferentially favor the $\beta$-oxidation of endogenous fatty acids, thereby lowering respiratory exchange ratios among postabsorptive individuals, as has been documented in humans. ${ }^{44,81}$ Previous studies of other snakes have documented general increases in respiratory exchange ratios during SDA $^{56,57}$ particularly in the early phases of digestion, there are no examples that repeatedly show such systematic increases in the respiratory exchange ratio during digestion in the literature.

Three nonmutually exclusive mechanisms are proposed that might explain the comparatively low respiratory exchange ratios documented during the early phases of digestion. First, significant hypoventilatory responses have been reported in digesting, but not exercising, pythons. ${ }^{54}$ Therefore, it is possible that the low respiratory exchange ratios during the early phases of digestion could stem from a respiratory acidosis caused by alkaline tides in the blood as hydrogen ions are routed into the gastric lumen. ${ }^{55,99,101-104}$ A second possibility is that the snakes lost carbon via nonventilatory means, such as bicarbonate excretion. ${ }^{51}$ It should be noted that although excretion events did not occur until the terminus of SDA, these snakes may have sequestered carbonrich waste products (eg, bicarbonate and uric acid) in the distal gut. ${ }^{105} \mathrm{~A}$ third possibility is that respiratory exchange 
ratios was depressed as a result of an $\mathrm{O}_{2}$ debt incurred during the ingestion process. ${ }^{85,106-109}$

Although no paleoatmospheric model has suggested that the Earth's atmosphere ever reached $50 \% \mathrm{O}_{2}$, it could be predicted that excessive $\mathrm{O}_{2}$ enrichment might additively contribute to the responses observed in $35 \% \mathrm{O}_{2}$ treatments, but this was apparently not the case. In fact, the lack of similarity between responses measured at $50 \%$ and $35 \% \mathrm{O}_{2}$ suggests the likelihood that additional physiologic costs may have been incurred. If the partial pressures of $\mathrm{O}_{2}$ in tissues increased beyond some limit, the snakes may have had to devote increasing energy to activities of antioxidants, including oxidases and catalases. ${ }^{110-113}$ Several studies report the toxic effects of hyperoxygenation in animals are not realized until inspired $\mathrm{O}_{2}$ levels exceed 50\%, ${ }^{111,113,114}$ but toxic effects have been reported in Drosophila chronically exposed to $40 \% \mathrm{O}_{2} \cdot{ }^{115}$

It is possible that, like other animals, improvements in other performance variables (eg, locomotion) might be realized by snakes under hyperoxic conditions, and future studies will be needed to explore the extent to which other performance variables are influenced by hyperoxia, as well as examine generality of the feeding responses to hyperoxia reported here, particularly in other species, such as pythons, that also devote a large proportion of their ingested energy to digestive costs. ${ }^{29,30}$ It will also be useful to examine whether similar responses are observed in individuals reared under or subjected to chronic hyperoxia.

For animals that are considered to be low-energy specialists, like many snakes, any savings in maintenance and/ or food processing costs could have substantial cumulative effects on survival and reproductive output, and ultimately their overall fitness. ${ }^{31,32,116-119}$ An understanding of the relationships between the environment and the physiology of ancient animals is not only requisite for accurate paleoecologic reconstructions, but also necessary to understand concomitant evolutionary trends that may have been shaped by paleoatmospheric changes. ${ }^{10-12}$

\section{Acknowledgment}

Thanks to SJ Beaupre for providing help with experimental design and the facilities to conduct this research.

\section{Disclosure}

The author reports no conflict of interest in this work.

\section{References}

1. Watson A, Lovelock JE, Margulis L. Methanogenesis, fires and the regulation of atmospheric oxygen. Biosystems. 1978;10:293-298.

2. Kerr RA. No longer willful, Gaia becomes respectful. Science. 1988; 240:393-395.
3. Lovelock JE. Geophysiology - the science of Gaia. Rev Geophys. 1989; 27:215-222.

4. Berkner LV, Marshall LC. On the origin and rise of oxygen concentration in the Earth's atmosphere. J Atmos Sci. 1965;22:225-261.

5. Robinson JM. Phanerozoic atmospheric reconstructions: A terrestrial perspective. Palaeogeog Palaeoclim Palaeoecol. 1991;97:51-62.

6. Berner RA. Drying, $\mathrm{O}_{2}$ and mass extinction. Nature. 1989;340: 603-604.

7. Bergman NM, Lenton TM, Watson AJ. COPSE: A new model of biogeochemical cycling over Phanerozoic time. Am J Sci. 2004;304: 397-437.

8. Berner RA. GEOCARBSULF: A combined model for Phanerozoic atmospheric $\mathrm{O}_{2}$ and $\mathrm{CO}_{2}$. Geochim Cosmochim Acta. 2006;70:5653-5664.

9. Hart MH. The evolution of the atmosphere of the Earth. Icarus. 1978; 33:23-39.

10. Clack JA. Devonian climate change, breathing, and the origin of the tetrapod stem group. Integr Comp Biol. 2007;47:510-523.

11. Fluck M, Webster KA, Graham JB, Giomi F, Gerlach F, Schmitz A. Coping with cyclic oxygen availability: Evolutionary aspects. Integr Comp Biol. 2007;47:524-531.

12. Dudley R. Atmospheric oxygen, giant Paleozoic insects and the evolution of aerial locomotor performance. J Exp Biol. 1998;201:1043-1050.

13. Kaiser A, Klok CJ, Socha JJ, Lee W, Quinlan MC, Harrison JF. Increase in tracheal investment with beetle size supports hypothesis of oxygen limitation on insect gigantism. Proc Natl Acad Sci U S A. 2007;104: 13198-13203.

14. Graham JB, Dudley R, Aguilar NM, Gans C. Implications of the late Paleozoic oxygen pulse for physiology and evolution. Nature. 1995;375: $117-120$.

15. Porter CA, Haiduk MW, de Queiroz K. Evolution and phylogenetic significance of ribosomal gene location in chromosomes of squamate reptiles. Copeia. 1994;2:302-313.

16. Dudley R. The evolutionary physiology of animal flight: Paleobiological and present perspectives. Annu Rev Physiol. 2000;62:135-155.

17. Suarez RK. Oxygen and the upper limits to animal design and performance. J Exp Biol. 1998;201:1065-1072.

18. Schwenk K. Feeding in lepidosaurs. In: Schwenk K, editor. Feeding: Form, Function, and Evolution in Tetrapod Vertebrates. New York, NY: Academic Press; 2000.

19. Wiens JJ, Slingluff JL. How lizards turn into snakes: A phylogenetic analysis of body-form evolution in anguid lizards. Evolution. 2001;55: 2303-2318.

20. Greene HW. Snakes: The Evolution of Mystery in Nature. Los Angeles, CA: University of California Press; 1997.

21. Dowling HG, Hass CA, Highton R. Snake relationships revealed by slowevolving proteins: A preliminary survey. J Zool. 1996;240:1-28.

22. Rage JC. Fossil history. In: Collins, JT, Novak SS, Seigel RA, editors. Snakes: Ecology and Evolutionary Biology. New York, NY: Macmillan; 1987.

23. Nowak EM, Theimer TC, Schuett GW. Functional and numerical responses of predators: Where do vipers fit in the traditional paradigms? Biol Rev. 2008;83:601-620.

24. Rage JC. Origin and evolution of snakes. In: Bauchot R, editor. Snakes: A Natural History. New York, NY: Sterling; 1997.

25. Weiner J. Physiological limits to sustainable energy budgets in birds and mammals: Ecological implications. Trends Ecol Evol. 1992;7: 384-388.

26. Congdon JD, Dunham AE, Tinkle DW. Energy budgets and life histories of reptiles. In: Pough FH, editor. Biology of the Reptilia. New York, NY: Academic Press; 1982.

27. Dunham AE, Grant BW, Overall KL. Interfaces between biophysical and physiological ecology and the population ecology of terrestrial vertebrate populations. Physiol Zool. 1989;62:335-355.

28. McCue MD. Specific dynamic action: A century of investigation. Comp Biochem Physiol. 2006;144A:381-394.

29. Secor S. Specific dynamic action: A review of the postprandial metabolic response. J Comp Physiol. 2008;179:1-56. 
30. Secor SM, Diamond J. A vertebrate model of extreme physiological regulation. Nature. 1998;395:659-662.

31. McCue MD, Lillywhite HB. Oxygen consumption and the energetics of island dwelling Florida cottonmouth snakes. Physiol Biochem Zool. 2002;75:165-178.

32. Beaupre SJ. Modeling time-energy allocation in vipers: Individual responses to environmental variation and implications for populations. In: Schwuett GW, editor. Biology of the Vipers. Eagle Mountain, UT: Eagle Mountain Publishing; 2002.

33. Beaupre SJ. An ecological study of oxygen consumption in the mottled rock rattlesnake, Crotalus lepidus lepidus, and the black-tailed rattlesnake, Crotalus molossus molossus, from two populations. Physiol Zool. 1993;66:437-454.

34. Beaupre SJ, Duvall DJ. Variation in oxygen consumption of the Western diamondback rattlesnake (Crotalus atrox): Implications for sexual size dimorphism. J Comp Physiol. 1998;168B:497-506.

35. Secor S, Nagy KA. Bioenergetic correlates of foraging mode for the snakes Crotalus cerastes and Masticophis flagellum. Ecology. 1994; 75:1600-1614.

36. Frappell PB, Schultz TJ, Christian KA. The respiratory system in varanid lizards: Determinants of $\mathrm{O}_{2}$ transfer. Comp Biochem Physiol. 2002;133A:239-258.

37. Jones JH, Lindstedt SL. Limits to maximal performance. Annu Rev Physiol. 1993;55:547-569.

38. Wang T, Hicks JW. An integrative model to predict maximum $\mathrm{O}_{2}$ uptake in live animals with central vascular shunts. Zoology. 2002; 105:45-53.

39. Weibel ER. Symmorphosis and optimization of biological design: Introduction and questions. In: Weibel ER, Taylor CR, Bolis L, editors. Principles of Animal Design: The Optimization and Symmorphosis Debate. Cambridge, MA: Cambridge University Press; 1998.

40. Glass ML, Wood SC. Gas exchange and control of breathing in reptiles. Physiol Rev. 1983;63:232-260.

41. Suarez RK. Upper limits to mass-specific metabolic rates. Annu Rev Physiol. 1996;58:583-605.

42. Knight DR, Schaffartzik W, Poole DC, Hogan MC, Bebout DE, Wagner PD. Effects of hyperoxia on maximal leg $\mathrm{O}_{2}$ supply and utilization in men. $J$ Appl Physiol. 1993;75:2586-2594.

43. Richardson RS. What governs skeletal muscle $\mathrm{VO}_{2 \max }$ ? New evidence. Med Sci Sport Exerc. 2000;32:100-107.

44. Welch HG. Hyperoxia and human performance: A brief review. Med Sci Sport Exerc. 1982;14:253-262.

45. MacDonald M, Pedersen PK, Houghson RL. Acceleration of VO2 kinetics in heavy submaximal exercise by hyperoxia and prior highintensity exercise. J Appl Physiol. 1997;83:1318-1325.

46. Jordan AD, Steffensen JF. Effects of ration size and hypoxia on specific dynamic action. Physiol Biochem Zool. 2007;80:178-185.

47. Jordan AD, Steffensen JF. Specific dynamic action in Gadus morhua under normoxia and moderate strong hypoxia. Comp Biochem Physiol. 2005;141A:S213.

48. Commission for Thermal Physiology of the International Union of Physiological Sciences. Glossary of terms for thermal physiology. Jpn J Physiol. 2001;51:245-280.

49. Allen WV. Biochemical aspects of lipid storage and utilization in animals. Am Zool. 1976;16:631-647.

50. Westerterp K. How rats economize - energy loss in starvation. Physiol Zool. 1977;50:331-362.

51. Walsberg GE, Wolf BO. Variation in the respiratory quotient of birds and implications for indirect calorimetry using measurements of carbon dioxide production. J Exp Biol. 1995;198:213-219.

52. Weber JM, O'Connor T. Energy metabolism of the Virginia opossum during fasting and exercise. J Exp Biol. 2000;203:1365-1371.

53. Castellini MA, Rea LD. The biochemistry of natural fasting at its limits. Experientia. 1992;48:575-582.

54. Secor SM, Hicks JW, Bennett AF. Ventilatory and cardiovascular response of a python (Python molurus) to exercise and digestion. J Exp Biol. 2000;203:2447-2454.
55. Overgaard J, Andersen JB, Wang T. The effects of fasting duration on the metabolic response to feeding in Python molurus: An evaluation of the energetic costs associated with gastrointestinal growth and upregulation. Physiol Biochem Zool. 2002;75:360-368.

56. Overgaard J, Busk M, Hicks JW, Jensen FB. Respiratory consequences of feeding in the snake Python molurus. Comp Biochem Physiol. 1999; 124A:359-365.

57. Wang T, Burggren W, Nobrega E. Metabolic, ventilatory, and acid-base responses associated with specific dynamic action in the toad Bufo marinus. Physiol Zool. 1995;68:192-205.

58. Busk M, Overgaard J, Hicks JW, Bennett AF, Wang T. Effects of feeding on arterial blood gases in the American alligator Alligator mississippiensis. J Exp Biol. 2000;203:3117-3124.

59. McCue MD. Western diamondback rattlesnakes demonstrate physiological and biochemical strategies for tolerating prolonged starvation. Physiol Biochem Zool. 2007;80:25-34.

60. McCue MD. Snakes survive prolonged fasting by employing supply-side and demand-side economic strategies. Zoology. 2007;110:318-327.

61. Forsman A, Lindell LE. Trade-off between growth and energy storage in male Vipera berus (L.) under different prey densities. Funct Ecol. 1991;5:717-723.

62. Lourdais O, Bonnet X, Shine R, Denardo D, Naulleau G, Guillon M. Capital-breeding and reproductive effort in a variable environment: A longitudinal study of a viviparous snake. J Anim Ecol. 2002;71:470-479.

63. Niewiarowski PH, Dunham AE. The evolution of reproductive effort in squamate reptiles: Costs, trade-offs, and assumptions reconsidered. Evolution. 1994;48:137-145.

64. Bonnet X, Lourdais O, Shine R, Naulleau G. Reproduction in a typical capital breeder: Costs, currencies, and complications in the aspic viper. Ecology. 2002;83:2124-2135.

65. Ladyman M, Bonnet R, Lourdais O, Bradshaw D, Naulleau G. Gestation, thermoregulation, and metabolism in a viviparous snake, Vipera aspis: Evidence for fecundity-independent costs. Physiol Biochem Zool. 2003;76:497-510.

66. Chu CW, Tsai TS, Tsai IH, Lin YS, Tu MC. Prey envenomation does not improve digestive performance in Taiwanese pit vipers (Trimeresurs gracilis and T. stejnegeri stejnegeri). Comp Biochem Physiol. 2009; 152A:579-585.

67. Secor SM, Diamond J. Evolution of regulatory responses to feeding in snakes. Physiol Biochem Zool. 2000;73:123-141.

68. Andrade DV, Cruz-Neto AP, Abe AS. Meal size and specific dynamic action in the rattlesnake Crotalus durissus (Serpentes: Viperidae). Herpetologica. 1997;53:485-493.

69. Zaidan F, Beaupre SJ. Effects of body mass, meal size, fast length, and temperature on specific dynamic action in the timber rattlesnake (Crotalus horridus). Physiol Biochem Zool. 2003;76:447-458.

70. McCue MD. Cost of producing venom in North American pitvipers. Copeia. 2006;4:818-825.

71. Beck DD. Ecology and energetics of three sympatric rattlesnake species in the Sonoran Desert. J Herpetol. 1995;29:211-223.

72. McCue MD. Prey envenomation does not improve digestive performance in Western diamondback rattlesnakes (Crotalus atrox). J Exp Zool. 2007;307:568-577.

73. Chappell MA, Ellis TM. Resting metabolic rates in boid snakes: Allometric relationships and temperature effects. J Comp Physiol. 1987; 157B:227-235.

74. Jobling M. The influences of feeding in the metabolic rate of fishes: A short review. J Fish Biol. 1981;18:385-400.

75. McNab BK. On the comparative ecological and evolutionary significance of total and mass-specific rates of metabolism. Physiol Biochem Zool. 1999;72:642-644.

76. McCue MD, Bennett AF, Hicks JW. The effect of meal composition on specific dynamic action in Burmese pythons (Python molurus). Physiol Biochem Zool. 2005;78:182-192.

77. Roe JH, Hopkins WA, Snodgrass JW, Congdon JD. The influence of circadian rhythms on pre- and post-prandial metabolism in the snake Lamprophis fuliginosus. Comp Biochem Physiol. 2004;139A:159-168. 
78. Lighton JRB. Measuring Metabolic Rates: A Manual for Scientists. New York, NY: Oxford University Press; 2008.

79. Hill AV, Long CNH, Lupton H. Muscular exercise, lactic acid, and the supply and utilization of oxygen: Parts IV-VI. Proc R Soc Med. 1924;97B:84-138.

80. Welch HG, Mullin JP, Wilson GD, Lewis J. Effects of breathing O2-enriched gas mixtures on metabolic rate during exercise. Med Sci Sports. 1974;6:26-32.

81. Wilson BA, Welch HG, Liles JN. Effects of hyperoxia gas mixtures on energy metabolism during prolonged work. J Appl Physiol. 1975; 39:267-271.

82. Shine R, Phillips B, Lankilde T, Lutterschmidt DI, Waye H, Mason RT. Mechanisms and consequences of sexual conflict in garter snakes (Thamnophis sirtalis, Colubridae). Behav Ecol. 2004;15: 654-660.

83. Gleeson TT, Hancock TV. Metabolic implications of a 'run now, pay later' strategy in lizards: An analysis of post-exercise oxygen consumption. Comp Biochem Physiol. 2002;133A:259-267.

84. Andersen JB, Wang T. Cardiorespiratory effects of forced activity and digestion in toads. Physiol Biochem Zool. 2003;76:459-470.

85. Pinz I, Portener HO. Metabolic costs induced by lactate in the toad Bufo marinus: New mechanism behind oxygen debt? J Appl Physiol. 2003;94:1177-1185.

86. Wickler SJ, Gleeson TT. Lactate and glucose metabolism in the mouse (Mus musculus) and reptile (Anolis carolinensis) skeletal muscle. Am J Physiol. 1993;264:R487-R491.

87. DuRant SE, Romero LM, Talent LG, Hopkins WA. Effect of exogenous corticosterone on respiration in a reptile. Gen Comp Endocrinol. 2008;156:126-133.

88. Gleeson TT, Dalessio PM. Lactate and glycogen metabolism in the lizard Dipsosaurus dorsalis following exhaustive exercise. J Exp Biol. 1989;144:377-393.

89. Donovan ER, Gleeson TT. Evidence for facilitated lactate uptake in lizard skeletal muscle. J Exp Biol. 2001;204:4099-4106.

90. Bennett AF. Activity metabolism of the lower vertebrates. Annu Rev Physiol. 1978;400:447-469.

91. Boyer DR. Interaction of temperature and hypoxia on respiratory and cardiac responses in the lizard, Sauromalus obesus. Comp Biochem Physiol. 1967;20:437-447.

92. Frankel HM, Spitzer A, Blaine J, Schoener EP. Respiratory response of turtles (Pseudemys scripta) to changes in arterial blood gas composition. Comp Biochem Physiol. 1969;31:535-546.

93. Klein W, Andrade DV, Wang T, Taylor EW. Effects of temperature and hypercapnia on ventilation and breathing pattern in the lizard Uromaxtyx aegyptius microlepis. Comp Biochem Physiol. 2002;132A: $847-859$

94. Burggren W, Pinder AW. Ontogeny of cardiovascular and respiratory physiology in lower vertebrates. Annu Rev Physiol. 1991;53: 107-135.

95. Delaney RG, Lahiri S, Fishman AP. Aestivation of the African lungfish Protopterus aethiopicus: Cardiovascular and respiratory functions. J Exp Biol. 1974;61:111-128.

96. Faraci FM. Adaptations to hypoxia in birds: How to fly high. Annu Rev Physiol. 1991;53:59-70.

97. Frappell PB, Schultz T, Christian K. Oxygen transfer during aerobic exercise in a varanid lizard Varanus mertensi is limited by the circulation. J Exp Biol. 2002;205:2725-2736.

98. Wang T, Taylor EW, Andrade DV, Abe AS. Autonomic control of heart rate during forced activity and digestion in the snake Boa constrictor. J Exp Biol. 2001;204:3553-3560.

99. Secor SM, Diamond J. Adaptive responses to feeding in Burmese pythons: Pay before pumping. J Exp Biol. 1995;198:1313-1325.

100. Secor SM, Diamond J. Effects of meal size on postprandial responses in juvenile Burmese pythons (Python molurus). Am J Physiol. 1997;272: R902-R912.

101. Secor SM. Stomach pH and the cost of gastric digestion for the Burmese python. Physiologist. 2002;45:345.
102. Secor SM. Gastric function and its contribution to the postprandial metabolic response of the Burmese python Python molurus. J Exp Biol. 2003;206:1621-1630.

103. Hartzler LK, Munns SL, Bennett AF, Hicks JW. Metabolic and blood gas dependence on digestive state in the savannah monitor lizard Varanus exanthematicus: An assessment of the alkaline tide. $J$ Exp Biol. 2006;209:1052-1057.

104. Wang T, Busk M, Overgaard J. The respiratory consequences of feeding in amphibians and reptiles. Comp Biochem Physiol. 2001;128A:535-549.

105. Lillywhite HB, de Silva P, Noonan BP. Patterns of gut passage time and chronic retention of fecal mass in viperid snakes. In: Schwuett GW, editor. Biology of the Vipers. Eagle Mountain, UT: Eagle Mountain Publishing; 2002.

106. Feder ME, Arnold SJ. Anaerobic metabolism and behavior during predatory encounters between snakes (Thamnophis elegans) and salamanders (Plethodon jordani). Oecologia. 1982;53:93-97.

107. Pough FH, Andrews RM. Energy costs of subduing and swallowing prey for a lizard. Ecology. 1985;66:1525-1533.

108. Kemper WF, Lindstedt SL, Hartzler LK, Hicks JW, Conley KE. Shaking up glycolysis: Sustained, high lactate flux during aerobic rattling. Proc Nat Acad Sci U SA. 2001;98:723-728.

109. Bennett AF. Integrated studies of locomotor performance. In: Wake DB, Roth G, editors. Complex Organismal Functions: Integration and Evolution in Vertebrates. Chichester, UK: J Wiley; 1989.

110. Frank L, Groseclose E. Oxygen toxicity in newborn rats: The adverse effects of undernutrition. $J$ Appl Physiol. 1982;53:1248-1255.

111. Clark JM. Oxygen toxicity. In: Kindwall EP, editor. Hyperbaric Medicine Practice. New York, NY; Best Publishing: 1995.

112. Sheikh AY, Gibson JJ, Rollins MD, Hopf HW, Hussain Z, Hunt TK. Effect of hyperoxia on vascular endothelial growth factor levels in a wound model. Arch Surg. 2000;135:1293-1297.

113. Jamieson D, Chance B, Cadenas E, Boveris A. The relation of free radical production to hyperoxia. Annu Rev Physiol. 1986;48: 703-719.

114. Whelan HT, Kindwall EP. Hyperbaric oxygen: Some unanswered questions despite clinical usefulness. In: Hudetz AG, Bruley DF, editors. Oxygen Transport to Tissue: XX. New York, NY: Plenum Press; 1998.

115. Baret P, Fouarge A, Bullens P, Lints FA. Life-span of Drosophila melanogaster in highly oxygenated atmospheres. Mech Aging Dev. 1994;76:25-31.

116. Brown WS. Female reproductive ecology in a northern population of the timber rattlesnake, Crotalus horridus. Herpetologica. 1991; 47:101-115.

117. Congdon JD. Proximate and evolutionary constraints on energy relations of reptiles. Physiol Zool. 1989;62:356-373.

118. Madsen T, Shine R. Determinants of reproductive success in female adders, Vipera berus. Oecologia. 1992;92:40-47.

119. Pough FH. The advantages of ectothermy for tetrapods. Am Nat. 1980; 115:92-112.

120. Dudley R, Winter Y. Hovering flight mechanics of neotropical flower bats (Phyllostomidae: Glossophaginae) in normodense and hypodense gas mixtures. J Exp Biol. 2002;205:3669-3677.

121. Lang DJ, Johnson PC. Elevated ambient oxygen does not affect autoregulation in cat mesentery. Am J Physiol. 1988;255:H131-H137.

122. Metcalf JA, McCutcheon IE, Francisco DL, Metzenberg AB, Welch JE. Oxygen availability and growth of the chick embryo. Respir Physiol. 1981;46:81-88.

123. Frazier MR, Woods HA, Harrison JF. Interactive effects of rearing temperature and oxygen on the development of Drosophila melanogaster. Physiol Biochem Zool. 2001;74:641-650.

124. Wittner M, Rosenbaum RM. Resistance and susceptibility to high oxygen pressures in the early development of the frog, Rana pipiens. Physiol Zool. 1958;31:294-303.

125. Knighton DR, Halliday B, Hunt TK. Oxygen as an antibiotic. Arch Surg. 1986;121:191-195. 
126. Dooley JW, Mehm WJ. Noninvasive assessment of the vasoconstrictive effects of hyperoxygenation. J Hyper Med. 1990;4:177-187.

127. Dor Y, Prorat R, Keshet E. Vascular endothelial growth factor and vascular adjustments to perturbations in oxygen homeostasis. $\mathrm{Am} \mathrm{J}$ Physiol. 2001;280:C1367-C1374.

128. Linnarsson D, Karlsson J, Fagraeus L, Saltin B. Muscle metabolites and oxygen deficit with exercise in hypoxia and hyperoxia. $J \mathrm{Appl}$ Physiol. 1974;36:399-402.

129. Welch HG, Bonde-Petersen F, Graham TE, Klausen K, Secher N. Effects of hyperoxia on leg blood flow and metabolism during exercise. J Appl Physiol. 1977;42:385-390.

130. Perry CGR, Talanian JL, Heigenhauser JF, Spriet LL. The effects of training in hyperoxia vs normoxia on skeletal muscle enzyme activities and exercise performance. J Appl Physiol. 2007;102:1022-1027.

131. Chai P, Harrykissoon R, Dudley R. Hummingbird hovering performance in hyperoxic heliox: Effects of body mass and sex. J Exp Biol. 1996;199:2745-2755.

132. Alexander G, Williams D. Summit metabolism and cardiovascular function in young lambs during hyperoxia and hypoxia. $J$ Physiol. 1970;208:85-97.

133. Andrews RM. Low oxygen: A constraint on the evolution of viviparity in reptiles. Physiol Biochem Zool. 2002;75:145-154.

134. Warner BB, Stuart LA, Papes RA, Wispe JR. Functional and pathological effects of prolonged hyperoxia in neonatal mice. Am J Physiol. 1998;275:L110-L117.
135. Williams JB, Swift K. Oxygen consumption and growth of northern bobwhite embryos under normoxic and hyperoxic conditions. Condor. 1988:90:187-192.

136. Fuller DD, Wang ZY, Ling L, Olson EB, Bisgard GE, Mitchell GS. Induced recovery of hypoxic phrenic responses in adult rats exposed to hyperoxia for the first month of life. J Physiol. 2001;536:917-926.

137. Ling L, Olson EB, Vidruk EH, Mitchell GS. Attenuation of the hypoxic ventilatory response in adult rats following one month of perinatal hyperoxia. J Physiol. 1996;495:561-571.

138. Crapo JD, Peters-Golden M, Marsh-Salin J, Shelburne JS. Pathological changes in the lungs of oxygen-adapted rats. Lab Invest. 1978;39: 640-653.

139. Harrison GA. Ultrastructural changes in rat lung during long-term exposure to oxygen. Exp Med Surg. 1971;29:96-107.

140. Hordnes C, Tyssebotn I. Effect of high ambient pressure and oxygen tension on organ blood flow in conscious trained rats. Undersea Biomed Res. 1985;12:115-128.

141. Smith JL. The pathological effects due to increase of oxygen tension in the air breathed. J Physiol. 1899;24:19-35.

142. Glass M, Johansen K. Control of breathing in Acrochordus javanicus, an aquatic snake. Physiol Zool. 1976;49:328-340.

143. Glass M, Burggren W, Johansen K. Ventilation in an aquatic and a terrestrial chelonian reptile. J Exp Biol. 1978;72:165-179.
Open Access Animal Physiology

\section{Publish your work in this journal}

Open Access Animal Physiology is an international, peer-reviewed, open access journal publishing original research, reports, reviews and commentaries on all areas of animal physiology. The manuscript management system is completely online and includes a very

\section{Dovepress}

quick and fair peer-review system. Visit http://www.dovepress.com/ testimonials.php to read real quotes from published authors. 